\title{
Sexual dimorphism in the squirrel monkey, Saimiri sciureus (Linnaeus, 1758) and Saimiri ustus (I. Geoffroy, 1844) (Primates, Cebidae)
}

\author{
Goldschmidt, B. ${ }^{\text {**, }}$ Mota-Marinho, A. ${ }^{\mathrm{a}}$, Araújo-Lopes, $C .{ }^{\mathrm{a}}$,

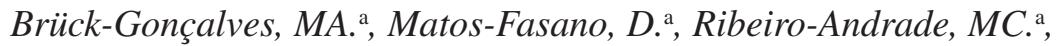 \\ Ferreira-Nascimento, LW. ${ }^{\text {a }}$,Simmer-Bravin, J. ${ }^{\mathrm{a}}$ and Monnerat-Nogueira, D. ${ }^{\mathrm{b}}$

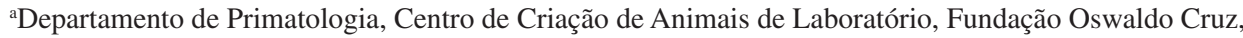 \\ Av. Brasil, 4365, Manguinhos, CEP 21040-900, Rio de Janeiro, RJ, Brazil \\ ${ }^{\text {b} F a c u l d a d e ~ d e ~ V e t e r i n a ́ r i a ~ d a ~ U n i v e r s i d a d e ~ F e d e r a l ~ F l u m i n e n s e, ~}$ \\ Rua Vital Brazil, 64, Niterói, RJ, Brazil \\ *e-mail: bibi@fiocruz.br
}

Received September 14, 2007 - Accepted December 10, 2007 - Distributed February 28, 2009

(With 1 figure)

\begin{abstract}
Causes and implications of sexual dimorphism have been studied in several different primates using a variety of morphological characters such as body weight, canine length, coat color and ornamentation. Here we describe a peculiar coat color characteristic in the squirrel monkey that is present only in adult females over five years old and which increases with age. Neither males nor young animals manifest this phenomenon, which is characterized by a spot of black hairs located anteriorly to the external ear (pinna). This characteristic could be used to discriminate adult females of Saimiri sciureus in the wild without the need of capture techniques.
\end{abstract}

Keywords: coat color, non-human primates, sexual maturity.

\section{Dimorfismo sexual em micos-de-cheiro, Saimiri sciureus (Linnaeus, 1758) e Saimiri ustus (I. Geoffroy, 1844) (Primates, Cebidae)}

\begin{abstract}
Resumo
As causas e implicações do dimorfismo sexual têm sido estudadas em diferentes espécies de primatas utilizando uma variedade de características morfológicas tais como peso corporal, comprimento de caninos, coloração do pelo e ornamentação. Este trabalho descreve uma característica peculiar da coloração do pelo em micos-de-cheiro, que está presente somente em fêmeas adultas após cinco anos de idade e que se acentua com a idade. Nem machos nem animais jovens manifestam esse fenômeno, que se caracteriza por uma mancha de pelos pretos localizada anteriormente à orelha. Esta característica poderia ser usada para discriminar fêmeas adultas de Saimiri sciureus na natureza sem necessidade de técnicas de captura.
\end{abstract}

Palavras-chave: cor de pelo, primatas não-humanos, maturidade sexual.

\section{Introduction}

Saimiri, so-called squirrel monkeys, is a genus of Neotropical primate that belongs to the Family Cebidae (Groves, 2001; 2005). Primates of this genus have short and thick coat and rounded off head. The snout is short and black, and the ears are rounded off. Pelage coloration presents a great variation amongst the species and subspecies. The extremity of the tail has a black tuff. Squirrel monkeys are distributed widely through Central and South America. Saimiri boliviensis is distributed through Brazil, Bolivia, Colombia, Peru and Venezuela. $S$. boliviensis boliviensis is found in Brazil, Peru, and Bolivia while S. boliviensis peruviensis is found only in the Peruvian Amazon (Groves, 2001; 2005; Gold, 2004). The Central American squirrel monkey, Saimiri oersteidii, is found in Costa Rica (both subspecies, S. oerstedi oerstedii and S. oerstedi citrinellis) and Panama (S. oerstedi oerstedii only) and is geographically separated from other species of squirrel monkeys found in South America (Groves, 2001; 2005). Molecular data has proved that $S$. oerstedii is, in fact, endemic to this region (Cropp and Boinski, 2000). Saimiri sciureus is distributed across several countries such as Brazil, Colombia, French Guiana, Guyana, Suriname and Venezuela. The species with the most restricted range is 
Saimiri vanzolinii, which can be found only on the left bank of Mamirauá Lake and at the mouth of the Japura River in Brazil (Ayres, 1985; Groves, 2001). Saimiri ustus is found in Brazil, to the south of the Amazon (Groves, 2001 ; 2005). Saimiri is important for many areas of biomedical research (Abee, 1985). Several species and subspecies differ in their physiological characteristics and susceptibility to illnesses. Therefore, the identification of the species and subspecies of Saimiri becomes an essential tool to the research in which they are used. Species and subspecies of squirrel monkeys have been assigned to the genus Saimiri however these classifications have been based on minor differences in coat coloration and are not clearly related to specific geographic regions. In this respect, karyotypic analyses have provided useful information on the chromosomal variation of these species (Jones et al., 1973). Sexual dimorphism in primate species expresses the effects of phylogeny, life history, behavior, and ontogeny. Different selective pressures presumably underlie these different patterns of dimorphism, and several theoretical models for the evolution of canine and body size dimorphism in primates have been proposed (Clutton-Brock et al., 1977; Leutenegger and Kelly, 1977; Clutton-Brock et al., 1985; Leigh, 1992; Martin et al., 1994; Oxnard, 2000). The degree of sexual dimorphism in a species may be a function of its overall body size and/or phylogenetic inertia (Leutenegger and Cheverud, 1982; 1985). The pattern of dimorphism, however, is usually attributed to some form of intraspecific competition (Plavcan and Van Schaik, 1992; 1997). The relationship between degree and pattern of dimorphism in the same species has not been explored closely. New World monkeys present an useful group for examining hypotheses of sexual dimorphism. Squirrel monkeys probably exhibit the most extensive geographic variation in social organization compared with other primates (Boinski and Cropp, 1999; Boinski, 1999). Radiation includes some well-defined monophyletic clades within which phylogeny can be controlled. Male and female of squirrel monkeys are seasonally sexually dimorphic and displays moderate body weight dimorphism, strong canine size dimorphism, and moderate cranial dimorphism (Thomas and Walter, 1998). Studying characteristics of sexual dimorphism in 610 specimens of Saimiri, from museum collections, Muniz (2005) observed sexual differences in the coloration pattern of the peri-auricular coat, describing it for the first time as an exclusive feature of adult females. The aim of this work is to characterize the pattern of peri-auricular coat coloration found in a captive colony of Saimiri sciureus and Saimiri ustus that can be used to discriminate sexes in these species.

\section{Material and Methods}

The Saimiri colony is kept in the Centre for Laboratory Animal Breeding of the Oswaldo Cruz Foundation, Fiocruz, Rio de Janeiro. It was established in 1987, housing animals rescued from the Balbina and Samuel hydroelectrical plant reservoir areas in the Amazon region. Eighty-four breeding animals compose the colony, of which 21 are S. ustus, 61 are S. sciureus and two hybrids between these two species. Once a year, all animals of the colony are submitted to medical management for treatment against parasites, tuberculin test, biometry, clinical examination, dental treatment and blood collection for hematological exams and the serum bank. During this handling, observing all animals of the colony, a darkening of the peri-auricular coat was observed in some. All animals of this colony have their karyotype analyzed, which characterize clearly each species. This breeding colony is maintained in compliance with Brazilian law and registered in IBAMA (Instituto Brasileiro do Meio Ambiente e dos Recursos Naturais Renováveis) under the protocol number 77933.

\section{Results}

It was observed that all males of the colony and all young of both sexes presented a clear peri-auricular coat (Figure 1a). From the 61 Saimiri sciureus, 33 were females. One noticed that in females of five years old
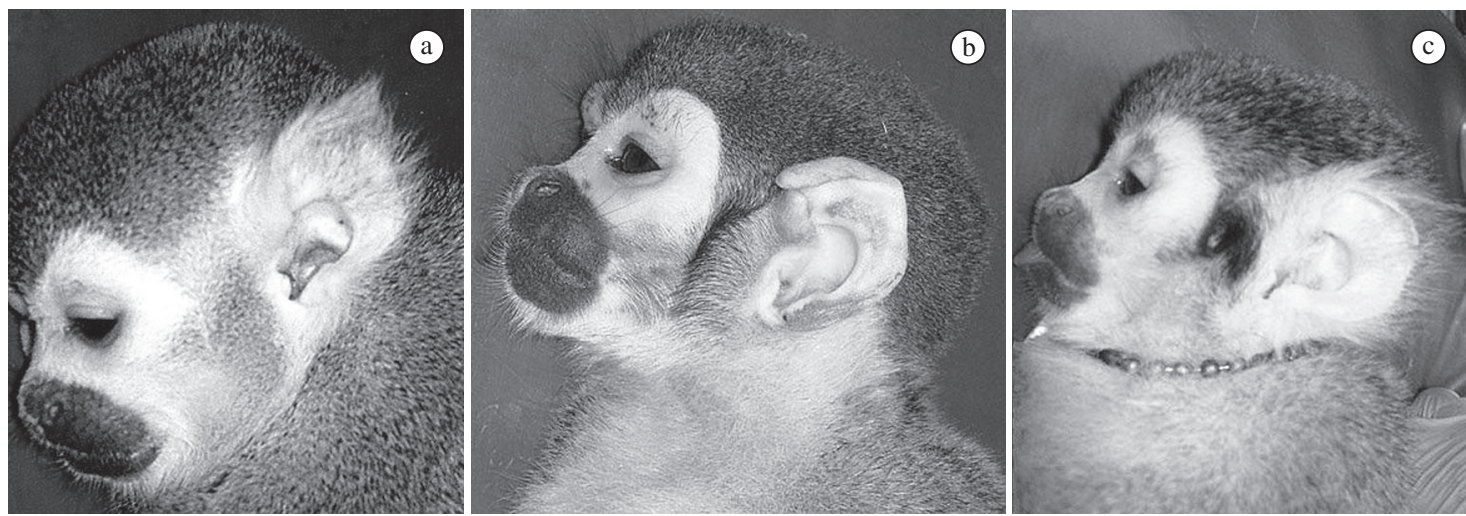

Figure 1. a) Old male Saimiri sciureus presenting a clear peri-auricular coat, b) female Saimiri ustus five years old, starting to present darkening of peri-auricular hairs, and c) Aged female Saimiri sciureus presenting a clear spot of blackish hair in the peri-auricular region of the external ear. 
( 5 females), this region becomes dark (Figure $1 \mathrm{~b}$ ) and in all aged females more than five-years-old (12 individuals), the peri-auricular coat was an extensive black spot (Figure 1c). In Saimiri ustus, the same phenomenon was observed in the 10 females of the colony: all females aged more than five years ( 5 animals) had a strong black spot, the only female of five years of age was starting to present this character and the remainder younger females (4 animals) did not present this character. The hybrid female between these two species was five years old and the darkening of the peri-auricular coat was beginning to appear.

\section{Discussion}

The phenomenon of sexual dichromatism, where males and females are differently colored within the same species, is common in vertebrates, particularly birds (Badyaev and Hill, 2000; Cuthill et al., 1999). Sexual dichromatism occurs notably among primates, where it may take the form of differences between males and females in whole-body coloration, e.g., in some species of howlers and gibbons, or may be restricted to certain areas around the genitalia (Dixson, 1998). In attempting to understand cause and effect in dimorphic outcomes the choice of characters alters the degree to which significant dimorphism can be detected (Leutenegger and Cheverud, 1985; Martin et al., 1994; Ford, 1994; Plavcan and Van Schaik, 1997). Recent studies of sexual dimorphism (Plavcan and Van Schaik, 1992; 1997; Ford, 1994) have identified the relative influences of diet, body size, phylogeny, and intraspecific competition in body weight and in canine size dimorphism. Sexual dimorphism in primate species expresses the effects of phylogeny, life history, behavior, and ontogeny. The causes and implications of sexual dimorphism have been studied in several different primates using a variety of morphological characters such as body weight, canine length, and coat color and ornamentation. In addition to these different patterns of dimorphism, the degree to which a species is dimorphic results from a variety of possible causes (Leutenegger, 1978; Cheverud, 1982; 1985; Cheverud et al., 1985). In the squirrel monkey, marked changes in hormonal levels exist between 1 and 3 years of age with puberty occurring in the females at approximately 2.5 years (Coe et al., 1981). If the females are small for their age, puberty can be delayed until 3.5 years of age but normally will be associated with the environmental cues that initiate the breeding season. There is a strong effect of body weight on hormone secretion and the onset of puberty in this species (Coe et al., 1985). According to Rowe (1996), female sexual maturity in Saimiri does not occur before 60 months. The peri-auricular black spot observed here in Saimiri adult females could be considered as a sexually dimorphic character since it has not been observed in males. The peri-auricular dark spot is an exclusive character of adult females, however it does not seem to be strictly related to ontogenesis. As the peri- auricular coat of the Saimiri females became black at the same time of sexual maturity (Rowe, 1996), we could suggest a hormonal mechanism of sexual dimorphism, which occurs in these Saimiri species related to age. The recognition of this characteristic could be useful to studies in the wild since the identification of sex and age range could be performed at a distance.

Aknowledgements - Authors thank FAPERJ - Fundação Carlos Chagas Filho de Amparo à Pesquisa do Estado do Rio de Janeiro, Brazil, which provide research and financial support

\section{References}

ABEE, CR., 1985. Medical care and management of the squirrel monkey. In ROSENBLUM, LA. and COE, CL.(Eds.). Handbook of Squirrel Monkey Research. New York: Plenum Press.

AYRES, JM., 1985. On a new species of squirrel monkey, Genus Saimiri, from Brazilian Amazonia (PRIMATES, CEBIDAE). Papéis avulsos de Zool., vol. 36, no. 14, p. 147-164.

BADYAEV, AV. and HILL, GE., 2000. Evolution of sexual dichromatism in birds: contribution of carotenoid- versus melanin-based plumage coloration. Biol. J. Linn. Soc., vol. 69, no. 2, p. 153-172.

BOINSKI, S., 1999. The social organizations of squirrel monkeys: implications for ecological models of social evolution. Evol. Anthropol., vol. 8, no. 3, p. 101-112.

BOINSKI, S. and CROPP, S., 1999. Disparate data sets resolve squirrel monkey (Saimiri) taxonomy: implications for behavioral ecology and biomedical usage. Int. J. Primatol., vol. 20, no. 2, p. $237-256$.

CHEVERUD, JM., 1982. Relationships among ontogenetic, static, and evolutionary allometry. Am. J. Phys. Anthropol., vol. 59 , no. 2 , p. 139-149.

-, 1985. A quantitative genetic model of altruistic selection. Behav. Ecol. Sociobiol., vol. 16, no. 3, p. 239-243.

CHEVERUD, JM., DOW, MM. and LEUTENEGGER, W., 1985. The quantitative assessment of phylogenetic constraints in comparative analyses: sexual dimorphism in body weight among primates. Evolution, vol. 39, no. 6, p. 1335-1351.

CLUTTON-BROCK, TH., HARVEY, PH. and RUDDER, B., 1977. Sexual dimorphism, socionomic sex ratio and body weight in primates. Nature (Lond.), vol. 269, p. 797-800.

CLUTTON-BROCK, TH., ALBON, S. and GUINNESS, FE., 1985. Parental investment and sex differences in juvenile mortality in birds and mammals. Nature, vol. 313, p. 131-133.

COE, CL., CHEN, J., LOWE, EL., DAVIDSON, JM. and LEVINE, S., 1981. Hormonal and behavioral changes at puberty in the squirrel monkey. Horm. Behav., vol. 15, no. 1, p. 36-53.

COE, CL., SMITH, ER. and LEVINE, S., 1985. The endocrine system of the squirrel monkey. In ROSENBLUM, LA. and COE, CL. (Eds.). Handbook of Squirrel Monkey Research. New York: Plenum. p. 191-218.

CUTHILl, IC., BENNETT, ATD., PARTRIDGE, JC. and MAIER, EJ., 1999. Plumage reflectance and the objective assessment of avian sexual dichromatism. Am. Nat., vol. 153, no. 2 , p. $183-200$. 
DIXSON, AF., 1998. Sexual selection and evolution of the seminal vesicles in primates. Folia Primatol. (Basel), vol. 69, no. 5, p. 300-306.

FORD, SM., 1994. Evolution of sexual dimorphism in body weight in platyrrhines. Am. J. Primatol., vol. 34, no. 2, p. 221-224.

GOLD, KC., 2004. New World monkeys I: squirrel monkeys and capuchins (Cebidae). In KLEIMAN, DG., GEIST, V. and McDADE, MC. (Eds.). Grzimek's animal life encyclopedia. Farmington Hills: Gale Group. p. 101-113.

GROVES, C., 2001. Primate taxonomy. Washington DC: Smithsonian Inst Pr. 350 p.

GROVES, CP., 2005. Order Primates. In WILSON, DE. and REEDER, DM. (Eds.). Mammal Species of the World. Baltimore: The Johns Hopkins University Press. p. 111-184.

JONES, TC., THORINGTON, RW., HU, MM., ADAMS, E. and COOPER, RW., 1973. Karyotypes of squirrel monkeys (saimiri sciureus) from defferent geographic regions. Am. J. Phys. Anthrop., vol. 38, no. 2, p. 269-277.

LEIGH, SR., 1992. Patterns of variation in the ontogeny of primate body size dimorphism. J. Hum. Evol., vol. 23, no. 1, p. 27-50.

LEUTENEGGER, W. and KELLY, JT., 1977. Relationship of sexual dimorphism in canine size and body size to social, behavioral and ecological correlates in anthropoid primates. Primates, vol. 18, no. 1, p. 117-136.
LEUTENEGGER, W. and CHEVERUD, J., 1982. Correlates of sexual dimorphism in primates: ecological and size variables. Int. J. Primatol., vol. 3, no. 4 p. 387-402.

,- 1985. Sexual dimorphism in primates: the effects of size. In JUNGERS, WL. (Ed.). Size and Scaling in Primate Biology. New York: Plenum Press. p. 33-50.

MARTIN, RD., WILLNER, LA. and DETTLING, A., 1994. The evolution of sexual size dimorphism in primates. In SHORT, RV. and BALABAN, E. (Eds.). The Differences Between the Sexes. Cambridge: Cambridge University Press. p. 159-200.

MUNIZ, ICM., 2005. Desenvolvimento do Dimorfismo nos macacos de cheiro (Saimiri VOIGT, 1831). Programa de Pós-Graduação em Zoologia da UFPA. 117p. Dissertação de Mestrado.

OXNARD, CE., 2000. Morphometrics of the primate skeleton and the functional and developmental under-pinnings of species diversity: development, growth and evolution. London: Academic Press.

PLAVCAN, JM. and Van SCHAIK, CP., 1992. Intrasexual competitionand canine dimorphism in anthropoid primates. Am. J. phys. Anthropol., vol. 87, p. 461-477.

-, 1997. Intrasexual competition and bodyweight dimorphism in anthropoid primates. Am. J. phys. Anthropol., vol. 103, p. 37-68.

ROWE, N., 1996. The pictorial guide to the living primates. East Hampton: Pogonias Pr. 263 p.

THOMAS, JM. and WALTER CH., 1998. Degrees of sexual dimorphism in cebus and other new world monkeys. Am. J. Physic. Anthropol., vol. 107, no. 3, p. 243-256. 